\begin{tabular}{c|c|c}
\hline \hline $\begin{array}{c}\text { Vol. 36(1):25-37 } \\
\text { http://dx.doi.org/10.4217/OPR.2014.36.1.025 }\end{array}$ & Ocean and Polar Research & March 2014 \\
\hline \hline
\end{tabular}

\title{
Article
}

\author{
생지화학적 지표를 이용한 서해안 갯벌 퇴적충에서의 \\ 유기물 순환에 관한 연구 \\ 이동헌 ${ }^{1,2} \cdot$ 이준호 $^{1 *} \cdot$ 정갑식 ${ }^{1} \cdot$ 우한준 $^{1} \cdot$ 강정원 $^{1} \cdot$ 신경훈 $^{2} \cdot$ 하선용 $^{3}$ \\ 1한국해양과학기술원 해양환경·보전연구부 \\ (426-744) 경기도 안산시 상록구 해안로 787 \\ 2한양대학교 과학기술대학 해양융합과학과 \\ (426-791) 경기도 안산시 상록구 한양대학로 55 \\ 3 한국해양과학기술원 부설 극지연구소 \\ (406-640) 인천광역시 연수구 송도미래로 26
}

\section{Organic Matter Cycle by Biogeochemical Indicator in Tidal Mud Flat, West Coast of Korea}

\author{
Dong-Hun Lee ${ }^{1,2}$, Jun-Ho Lee ${ }^{*}$, Kap-Sik Jeong ${ }^{1}$, Han jun Woo ${ }^{1}$, Jeongwon Kang ${ }^{1}$, \\ Kyung-Hoon Shin ${ }^{2}$, and Sun-Yong $\mathrm{Ha}^{3}$ \\ ${ }^{1}$ Marine Environments \& Conservation Research Division, KIOST \\ Ansan 426-744, Korea \\ ${ }^{2}$ Department of Marine Sciences and Convergent Technology, College of Science and Technology \\ Hanyang University, Ansan 426-791, Korea \\ ${ }^{3}$ Korea Polar Research Institute, KIOST \\ Incheon 406-640, Korea
}

\begin{abstract}
To understand the degradation processes of organic matter related to sulfate reduction by Sulfate Reduction Bacteria (SRB) in the tidal flat sediments of Hwang-do and Sogeun-ri, Tae-an Peninsula in Chungnam-do, biogeochemical characteristics were analyzed and highlighted using specific microbial biomarkers. The organic geochemical parameters (TOC, $\delta^{13} \mathrm{C}_{\text {org }}, \mathrm{C} / \mathrm{N}$ ratio, long-chain-n-alkane) indicate that most of the organic matter has been derived from marine phytoplankton and bacteria in the fine-grained sediment of Sogeun-ri, although terrestrial plant components have occasionally been incorporated to a significant degree in the coarse-grained sediment of Hwang-do. The concentration of sulfate in pore water is a constant tendency with regard to depth profile, while methane concentration appears to be slightly different with regard to depth profile at the two sites. Especially, the sum of bacteria fatty acid $(a-\mathrm{C} 15: 0+i-\mathrm{C} 15: 0+$ C16:1w5) confirms that the these concentrations in Sogeun-ri are related to the degradation of Benzene, Toluene, Ethylbenzene and Xylene (BTEX) compounds from the crude oil retained in the sediments as a result of the Hebei Spirit oil-spill accident in 2007. The methane-related microbial communities as shown by lipid biomarkers (crocetane, PMI) are larger in some sedimentary sections of Hwang-do than in the Sogeunri tidal flat. These findings suggest that methane production by microbiological processes is clearly governed by SRB activity along the vertical succession in organic-enriched tidal flats.
\end{abstract}

Key words : tidal flat, organic matter, lipid biomarker, stable carbon isotope, sulfate reduction bacteria

*Corresponding author. E-mail : leejh@kiost.ac 


\section{1. 서 론}

갯벌(tidal flat)은 육지와 바다 환경이 만나는 점이지역 으로 연안해양과 기수역의 유기물의 분해와 영양염 순환 에 큰 영향을 끼친다. 갯벌 퇴적물 내에서는 박테리아, 미 세조류 및 원생동물 등 다양한 미생물들의 호흡기작 중 유기물 분해를 통해 유기탄소가 무기탄소로 전환되는 생 지화학적 물질순환이 이루어질 뿐만 아니라, 재생산된 영 얌염들은 다시 연안의 수층으로 공급되어 일차생산에 결 정적인 영향을 끼친다(Alongi 1995; Jahnke 1995; Giblin et al. 1997). 일반적으로 갯벌을 포함한 연안해양 퇴적층 에는 유기물의 유입이 이를 분해할 수 있는 산소의 공급 보다 훨씬 빨라 산소를 공급하는 수층 또는 대기와 접하 는 퇴적층의 표층 수 $\mathrm{mm}$ 또는 수 $\mathrm{cm}$ 깊이에서부터 거의 항상 혐기성 환경이 형성된다(Thamdrup and Canfield 1996; Thamdrup 2000). 혐기성 퇴적 환경에서는 황산염이 풍부 하게 존재하여 황산염 환원 박테리아(Sulfate Reduction Bacteria)가 대부분의 유기물을 분해한다(Jørgensen 1982; Holmer 1996; Hyun et al. 2004). 특히 황산염 환원 박테 리아는 호흡 에너지 획득에 필요한 전자 공여체인 수소, 알코올, 지방산 등 100 종이 넘는 대사물질을 이용할 수 있 으며, 방항족 탄화수소와 같은 독성 유기물질이나 생체 이 물질(xenobiotic substance) 등 다양한 오염물질의 분해에 핵심적인 역할을 하기도 한다(Hansen 1993; Ensley and Sulflita 1995). 황산염이 결핍된 경우를 제외한 일반적인 해양퇴적환경에서, 메탄 생성기작에 의한 최종 유기물 분 해는 총 유기물 분해량의 $10 \%$ 미만으로, 황산염 환원 박 테리아의 황산염 환원활동이 거의 완료된 후에 시작된다 (Martens and Berner 1974; Oremland and Polcin 1982; Capone and Kiene 1988). 이때에는 메탄 생성 미생물들과 황산염 환원 박테리아가 $\mathrm{H}_{2}$ 나 acetate 등과 같은 전자 공 여체 수용을 연속적으로 또는 동시에 공통 기질에서 경쟁 하여, 메탄 생성 미생물의 호흡기작이 강화되면 반대로 황 산염 환원 박테리아의 활성은 감소한다(Minami et al. 1988; Koster et al. 1986). 혐기성 환경에서 독성 유기물질 의 분해는 서식 미생물들이 다양한 전자 수용체를 이용하 는 데 있어 퇴적환경의 산화환원 전위, $\mathrm{pH}$ 등과 같은 물 리화학적 환경차이 등에 따라 상대적인 차이가 있을 수 있다(Beller et al. 1992). 유류 오염물질(Benzene, Toluene, Ethylbenzene, Xylene, BTEX)들은 고둥과 같은 복족류의 먹이 섭취에 장애를 일으키고, 미생물들이 이들을 분해 시 산소의 소모로 인한 퇴적물의 혐기성화에 따른 생태적 피 해도 보고되고 있다(Jhonston 1970; Samiullah 1985).

지질생체지표들은 상대적으로 안정하여 쉽게 분해되지 않는 특징을 가지고 있으며, 퇴적물 내의 유입된 유기물의 거동, 재순환(remineralization) 및 기원뿐 만 아니라 서식
하고 있는 미생물들의 대사경로까지 파악할 수 있다는 장 점이 있다(Elvert et al. 2003; Blumberg et al. 2004). 또한, 메탄의 혐기성 산화와 황산염 환원이 활발한 퇴적환경에 서 나타난 다양한 지질생체지표들은 특정 미생물에게서 나타나는 결과로서 퇴적물 내 혐기성 유기물 분해를 파악 하는 유용한 지시자(indicator)로서 이용되고 있다(Elvert et al. 1999; Hinrichs et al. 1999; Pancost et al. 2001; Lee et al. 2013). 예를 들면, 해저 내 메탄의 혐기성 산화와 동 시에 황산염 환원이 활발하게 나타나는 퇴적층에서 메탄 을 탄소원으로서 사용하는 미생물의 지질생체지표로는 2,6,11,15-tetramethylhexadecane(crocetane), 2,6,10,15,19pentamethylicosane(PMI) 등이 있으며, 이들의 화합물들은 메탄의 거동을 파악하는데 유용하게 사용될 뿐 만 아니라 메탄의 방출이 활발한 퇴적층에서 주로 검출된바 있다 (Thiel et al. 1999; Maslen et al. 2009). 황산염 환원과 관 계있는 황산염 환원 박테리아는 분석된 각 지방산 중 $a-$ $\mathrm{C} 15: 0+i-\mathrm{C} 15: 0+\mathrm{C} 16: 1 w 5$ 의 합을 통해 표현될 수 있으 며, 이들의 농도는 미생물의 상대적인 생체량을 나타낼 뿐 만 아니라 서로 다른 퇴적환경에 따라 차이가 나타날 수 있다(Feio et al. 1988; Dzierzewicz et al. 1996; KIGAM 2011; Yang et al. 2011).

우리나라 서해안 갯벌에서의 미생물에 의한 혐기성 유 기물 분해능력과 그 중요성에 대한 연구는 황산염 환원력 측정, 저서생물에 의한 퇴적물 교란(bioturbation), 퇴적물 내 서식하는 미생물들의 다양성에 근거하여 수행된 바 있 다(Hyun et al. 2004; Cho et al. 2004; Mok et al. 2005). 또한 국내에서 지질생체지표를 이용하여 메탄 하이드레이 트를 포함하는 퇴적물 내에서 미생물에 의한 유기물의 순 환 및 메탄의 거동에 관한 연구가 보고된 바 있으나(Yang et al. 2011; Lee et al. 2013), 연안의 갯벌 퇴적물에서는 이러한 연구가 아직까지 진행된 바 없다.

따라서, 본 연구는 비교적 자연상태를 유지하고 있는 서해안 갯벌 퇴적물과 원유 유출로 오염된 적이 있는 갯 벌에서 첫째, 지화학 분석을 통해 유입되는 유기물의 기원 을 파악하여 연구지역간의 퇴적환경 차이를 추정하며, 둘 째, 지질생체지표의 정량 및 정성분석을 통해 혐기성 환경 의 퇴적층 깊이에 따른 $\mathrm{SRB}$ 와 메탄생성 미생물에 의한 유기물 분해 과정을 이해하고자 한다.

\section{2. 재료 및 방법}

\section{연구지역}

본 연구지역 중 하나인 황도 갯벌은 서해 중부 충청남 도 태안군 천수만의 북서쪽에 위치하며, 폭 $1.65 \mathrm{~km}$, 길이 $5.15 \mathrm{~km}$ 의 면적을 가지고 있다(Choi and Ryu 2011) (Fig. 1). 천수만은 만 입구와 안면도 연육교 밑의 수로를 통하 

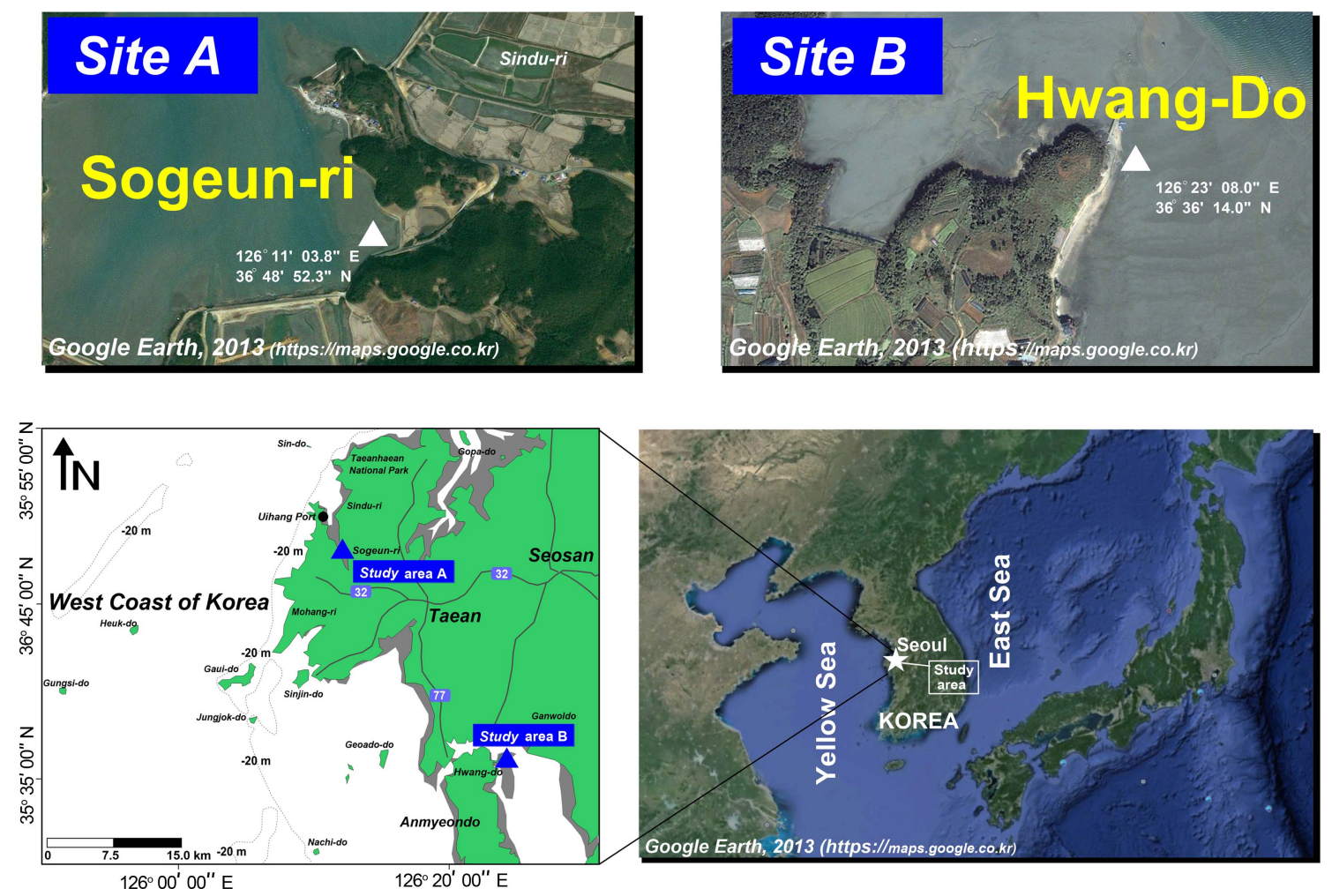

Fig. 1. Sampling sites in Hwang-Do (A) and Sogeun-ri intertidal flat (B), mid-west coast of Korea

여 해수 유통이 이루어지는 반폐쇄성 내만으로 비교적 자 연적인 갯벌의 형태를 유지하고 있으며, 서산 $\mathrm{A}, \mathrm{B}$ 지구 간척사업이 진행되기 전인 1980년대 이전에는 하천을 통 한 오염물질의 유입이 거의 없는 청정해역으로 생물 건강 성이 매우 좋았다(Woo et al. 2005). 현재는 간척지로부터 상당량의 비료나 농작물 잔해가 유입되고 있는 것으로 보 이며, 황도 갯벌의 중심부에는 조류로와 세곡이 복잡하게 발달되어 있으며(Kim 1989), 표층 퇴적물은 대체적으로 실트 모래(silt sand), 자갈이 약간 함유된 뻘모래(slightly gravelly muddy sand)로 구성되어 있다.

소근리 갯벌은 신두리 사구의 남단에 위치하여 의항항 과 신두리를 경계로 한 만형의 갯벌로 면적은 약 $3.0 \mathrm{~km}^{2}$ 이다(MOF 2005). 소근리 갯벌에서는 2007년 태안 앞바 다에서 발생한 Hebei Spirit의 유류 유출사고시 연안과 갯 벌에서 유출된 유류 방제작업을 수행하였으나, 폐쇄적인 지형적 특징으로 인해 완전히 제거되지 않고 퇴적물에서 지속적으로 유분이 확인되고 있다(KIOST 2011). 표층 퇴 적물은 자갈 뻘(gravelly mud), 자갈이 약간 함유된 모래 뻘(slightly gravelly sandy mud)로 구성되어 있다.

\section{퇴적물 채취 및 분석방법} 퇴적물 채취

2013년 2월 두 지역의 상부 갯벌에서 길이 $50 \mathrm{~cm}$, 직경
$66 \mathrm{~cm}$ 의 아크릴 코어를 이용하여 퇴적물 시료를 채취하였 다(Fig. 1). 채취된 코어는 깊이에 따라 일정한 간격으로 절개하여 입도, 지화학( $\mathrm{TOC}, \mathrm{C} / \mathrm{N}, \delta^{13} \mathrm{C}_{\mathrm{org}}, \mathrm{CH}_{4}, \mathrm{SO}_{4}{ }^{2-}$ ) 및 미생물 지질생체지표 분석용으로 나누어 취한 후 실험 목적에 따라 다음과 같이 전처리 및 분석을 행하였다.

\section{퇴적물 입도 및 지화학 분석}

코어의 깊이에 따라 채취한 퇴적물 시료는 먼저 $5 \mathrm{~g}$ 씩 을 $1 \mathrm{~L}$ 비이커에 넣고 순수 쇄설성 퇴적입자만 남도록 $10 \%$ 의 묽은 과산화수소 $\left(\mathrm{H}_{2} \mathrm{O}_{2}\right) 500 \mathrm{~mL}$ 와 24 시간동안 반 응시켜 저온에서 가열한 후 유기물을 제거하였다. 증류수 로 염분과 분해된 유기물을 씻어 낸 후, 다시 $1 \mathrm{~N}$ 염산 $(\mathrm{HCl})$ 을 첨가하여 12 시간 반응 후 패각편 등의 생물기원 탄산염질을 완전히 제거함으로써 조개껍질 등으로 인해 발생할 수 있는 퇴적물 입도분포의 오차범위를 최소화하 였다. 유기물과 탄산염이 제거된 퇴적시료는 $4 \phi(0.0625$ $\mathrm{mm}$ ) 체로 습식체질(wet sieving)하여 체에 남은 $4 \phi$ 이하 의 조립질과 체를 통과한 세립질 퇴적물로 분리하였다. $4 \phi$ 이하의 조립질 시료는 $0.5 \phi$ 간격의 체가 단계별로 장 착된 진탕체질기(ro-tap sieve shaker)를 이용하여 15분간 체질한 후 입도 등급별로 무게 백분율을 구하였다. $4 \phi$ 이상의 세립질 시료는 확산제 $(80 \mathrm{~mL}$ 의 $0.1 \%$ 칼곤용액 $)$ 를 넣고 초음파분쇄기와 자기진동기로 시료를 균일하게 
분산시킨 후 X-선 자동입도분석기인 Sedigraph 5100 (Micromeritics Instruments Co.)으로 분석하여 입도 무게 백분율을 구하였다. 계산된 각 입도 등급별의 무게 백분율 을 Folk and Ward (1957)의 방법에 따라 퇴적상을 구분하 고 평균입도를 구하였다.

퇴적물 내 총 유기탄소(TOC)와 총 질소(TN)의 함량 및 탄소안정동위원소비 $\left(\delta^{13} \mathrm{C}_{\text {org }}\right)$ 분석을 위하여 채취된 퇴적 시료를 동결 건조하였다. 동결 건조된 퇴적물을 균질 분쇄 하여 $0.5 \mathrm{~g}$ 의 시료에 $1 \mathrm{~N}$ 염산 $(\mathrm{HCl}) 10 \mathrm{~mL}$ 를 첨가하여 무 기탄소를 제거한 후 정량하여 tin capsule에 담아 EAirMS(elemental analyzer-isotope ratio mass spectrometry, EuroEA-Isoprime irms, GV instruments, UK)를 이용하여 분석을 실시하였다. $\delta^{13} \mathrm{C}_{\mathrm{org}}$ 는 다음과 같은 방정식에 따라 계산되었다.

$$
\delta \mathrm{X}=\left[\left(\mathrm{R}_{\text {sample }} \mathrm{R}_{\text {standard }}\right)-1\right] \times 1000(\%)
$$

$\mathrm{X}$ 는 ${ }^{13} \mathrm{C}$ 를 $\mathrm{R}$ 은 ${ }^{13} \mathrm{C} /{ }^{12} \mathrm{C}$ 를 나타내며, $\mathrm{PDB}(\mathrm{Pee}$ Dee Belemnite)를 표준물질로 사용하여 델타 $(\delta)$ 표기법으로 표 현하였다. $\delta^{13} \mathrm{C}$ 는 $0.2 \%$ 의 정확도로 측정되었다.

메탄 $\left(\mathrm{CH}_{4}\right)$ 분석은 퇴적층 별로 일정량의 퇴적물 시료 $(10 \mathrm{~mL})$ 를 serum bottle $(250 \mathrm{~mL})$ 에 넣은 후 고무마개로 즉각 밀봉하여 일정공간을 상부(headspace)에 만든 후 일 정량의 공기를 채취하여 $\mathrm{GC}(\mathrm{Gas}$ Chromatograph, GC6890, Agilent)를 이용하여 측정하였다. 이 때 Rt-QPLOT 컬럼(길이 $30 \mathrm{~m}$, 내경 $0.32 \mathrm{~mm}$, 필름 두께 $0.10 \mu \mathrm{m}$, Restek) 을 사용하였으며, 수소불꽃이온화검출기(Flame Inonization Detector)를 이용하였다. 운반가스는 $99.999 \%$ 의 고순도 헬륨 $(\mathrm{He})$ 을 사용하였다. 분석에 사용한 $\mathrm{CH}_{4}$ 표준기체 (standard gas)의 농도는 1, 10 및 $100 \mathrm{ppm}$ 으로 모두 농도 오차는 $3 \%$ 이내였다. 시료분석 전에 정밀성과 재현성 조 사를 위해 $\mathrm{GC}$ 는 약 12 시간 충분히 안정화시킨 후, $\mathrm{CH}_{4}$ 표준기체를 3회씩 분석하였으며, 피크(peak) 면적과 재현 시간을 각각 조사하였다. 반복정밀성 $(\mathrm{RSD}=$ 표준편차 / 평균값 $\times 100 \%$ )는 0.7-4.5\%였으며, 직선성 (linearity)을 나 타내는 다중 검량선 확인 결과 $\mathrm{R}^{2}=0.9888$ 이상이었다.

공극수의 황산염 $\left(\mathrm{SO}_{4}{ }^{2-}\right)$ 분석을 위해 채취된 퇴적물을 갯벌 내 혐기성 퇴적환경의 조건과 같게 만들어 주기 위 해 질소가스로 충진된 챔버 안에서 $2 \mathrm{~cm}$ 간격으로 나눈 후 압착 여과하여 추출된 공극수를 취하여 syringe filter (MFS-25, CA, $0.2 \mu \mathrm{m}$ )로 부유물을 제거시켰다. 이후 공 극수 중 $2 \mathrm{~mL}$ 을 취하여 $4 \mathrm{~mL}$ 의 폴리에틸렌(PE) 병에 담 고, 화학적 변화 $(\mathrm{pH})$ 를 방지하기 위해 $20 \mu \mathrm{L}$ 의 $35 \%$ 의 진 한 염산 $(\mathrm{HCl})$ 을 넣은 후 분석 전까지 냉동 보관하였으며, You et al. (2010)이 분석한 방법으로 이온 크로마토그래 피(761 Compact IC, Metrohm)를 이용하여 황산염 농도 를 측정하였다.

\section{지질생체지표 분석}

지질생체지표 분석을 위해 균질하게 분쇄된 퇴적물 시 료 10-20 g을 정량하여, 내부 표준물질(Internal Standard, I.S: fatty acid-heneicosanoic acid, Aldrich Co.; alcoholnonadecanol, Aldrich Co.; hydrocarbon-5-alpha-cholestane, Accustandard Co.)을 각각 첨가하였다. 지질은 가속용매추 출기(Accelerated Solvent Extraction, ASE)에 넣고 혼합비 율 99:1의 유기용매 Dichloromehtane/Methanol(DCM/ $\mathrm{MeOH})$ 를 이용하여 추출하였다. 추출된 시료는 질소가스 를 사용하여 용매를 제거한 뒤 얻어진 잔류물 $(50-100 \mu \mathrm{L})$ 에 $6 \% \mathrm{KOH}(4 \mathrm{~mL})$ 용액을 첨가하여 $80^{\circ} \mathrm{C}$ 에서 3 시간 동 안 비누화(saponification)을 실행한 후 n-hexane을 사용하 여 중성지질을 추출하였다. 중성지질은 실리카 컬럼(silica column)을 사용하여 hydrocarbon, alcohol로 분리하였으며, hydrocarbon 분리용매로는 n-hexane/dichlomethane( $95 / 5$, $\mathrm{v} / \mathrm{v}, 5 \mathrm{~mL}$ ), alcohol 분리를 위해서는 dichlomethane/ acetone $(9 / 1, \mathrm{v} / \mathrm{v}, 5 \mathrm{~mL})$ 를 이용하였다. 최종적으로 분리된 혼합물들은 $2 \mathrm{~mL} \mathrm{GC}$ vial에 $0.5 \mathrm{~mL}$ 씩 농축하였고, alcohol은 $100 \mu \mathrm{L}$ 의 pyridine과 $10 \mu \mathrm{L}$ 의 BSTFA(N, O-bis trifluoroacetamide with trimethylchloroilane, Aldrich Co.) 를 넣어준 뒤 $70^{\circ} \mathrm{C}$ 오븐에서 1 시간 동안 유도체화를 실행 한 뒤 n-hexane을 사용하여 최종적으로 추출하였다. 중성 지질 추출이 끝난 시료는 극성지질을 추출하기 위해 염산 을 첨가하여 반응시킨 뒤 $n$-hexane을 사용하여 추출하였 다. 추출이 완료된 시료에 $12-14 \% \mathrm{BF}_{3}-\mathrm{MeOH}$ (Alrich $\mathrm{Co}$.)를 첨가한 뒤 $60^{\circ} \mathrm{C}$ 오븐에 1 시간 동안 유도체화하여 최종적으로 $\mathrm{n}$-hexane을 사용하여 추출하고 $2 \mathrm{~mL} \mathrm{GC}$ vial 에 $0.5 \mathrm{~mL}$ 씩 농축시킨 후 분석에 사용하였다.

추출된 시료들은 $\mathrm{GC}($ Shimadzu QP2010)를 이용하여 분석하였으며, 미리 첨가한 내부표준물질을 이용하여 정 량화하였다. 성분 분리를 위하여 모세관 칼럼 DB-5(fused silica column : 길이 $30 \mathrm{~m}$, 내경 $0.32 \mathrm{~mm}$, 필름 두께 $0.25 \mu \mathrm{m}$, Agilent J\&W)를 사용하였고 검출기로서는 FID 를 이용하였다. 중성지질 분석 시 주입구 온도는 $60^{\circ} \mathrm{C}$ 로 1 분간 유지시킨 후 오븐의 온도는 $10^{\circ} \mathrm{C} / \mathrm{min}$ 속도로 $150^{\circ} \mathrm{C}$ 까지, $4^{\circ} \mathrm{C} / \mathrm{min}$ 속도로 $310^{\circ} \mathrm{C}$ 까지 상승시켜 50 분간 유지 시켰다. 극성지질 분석 시 주입구 온도는 $60^{\circ} \mathrm{C}$ 로 1 분간 유지시킨 후 오븐의 온도는 $10^{\circ} \mathrm{C} / \mathrm{min}$ 속도로 $150^{\circ} \mathrm{C}$ 까지, $2^{\circ} \mathrm{C} / \mathrm{min}$ 속도로 $230^{\circ} \mathrm{C}$ 까지, $5^{\circ} \mathrm{C} / \mathrm{min}$ 속도로 $310^{\circ} \mathrm{C}$ 까지 상승시켜 20 분간 유지시켰다. 분석시 $\mathrm{GC}$ 내 운반가스는 99.999\%의 고순도 헬륨을 사용하였다. 탄화수소 및 지방 산 성분들의 피크(peak)는 각각의 표준물질과 비교하여 정량화되었다.

탄화수소 및 지방산의 정성분석을 위하여 GC-MS (Shimadzu QP2010)를 이용하였다. Full scan mass spectra 는 탄화수소는 $40-600 \mathrm{~m} / \mathrm{z}$, 지방산은 $40-500 \mathrm{~m} / \mathrm{z}$ 으로 설 
정해 주었으며, 성분 분리는 $\mathrm{GC}$ 와 같은 온도조건으로 맞췄다. 탄화수소 및 지방산 성분들은 Greenwood and Summons (2003)의 GC-MS 결과와 비교하여 정성화되었 으며, 황산염 환원 박테리아의 상대적인 함량은 지방산(a$\mathrm{C} 15: 0, \mathrm{i}-\mathrm{C} 15: 0, \mathrm{C} 16: 1 w 5)$ 의 합으로 산출되었다.

\section{3. 결 과}

\section{퇴적물의 지화학적 특성}

2013년 2월 현장조사 기간에 황도와 소근리 지역의 퇴 적물 평균입도는 4.39-6.91 $\phi, 5.81-6.77 \phi$ 이며, 온도는 각각 $16.8-19.1^{\circ} \mathrm{C}, 15.1-17.1^{\circ} \mathrm{C}$ 범위였고 깊이에 따른 특별한 변화는 없었다(Fig. 2, Table 1). 전반적으로 모래 실트(sandy Silt)가 주인 황도와 점토실트(clayey Silt)로 구성된 소근리 퇴적물 코어의 밀도는 각각 $1.74-1.97 \mathrm{~g} /$ $\mathrm{cm}^{3}, 1.64-1.90 \mathrm{~g} / \mathrm{cm}^{3}$, 공극은 0.46-0.60, 0.51-0.58의 범 위로 두 지역에서 비슷한 값을 보였다. 한편, $\mathrm{TOC}$ 는 소근 리에서 0.41-0.73\%의 범위로 황도(0.18-0.29\%, $22 \mathrm{~cm}$ : $0.81 \%$ 제외)에서보다 2배 정도 높은 양을 보인다(Fig. 2, $3)$. 코어 퇴적물의 $\delta^{13} \mathrm{C}$ 은 황도에서 $-19.35--23.45 \%$ 이며, 소근리에서는 $-21.01-22.83 \%$ 로 황도에서보다 소근리 의 $\delta^{13} \mathrm{C}$ 값의 수직적 분포 변화가 적었다. $\mathrm{C} / \mathrm{N}$ 비의 경 우, 황도 코어 퇴적물의 퇴적 깊이 $22 \mathrm{~cm}$ 에서 아주 높은 값(24.93)을 제외하고 대부분 7.01-11.47의 범위를 나타냈 다(Fig. 2). 특히, 두 지역의 코어 퇴적물 중 $\mathrm{TOC}, \mathrm{C} / \mathrm{N}$ 비 가 높은 깊이에서는 $\delta^{13} \mathrm{C}$ 의 값이 현저히 감소하는 것으로 나타났다.

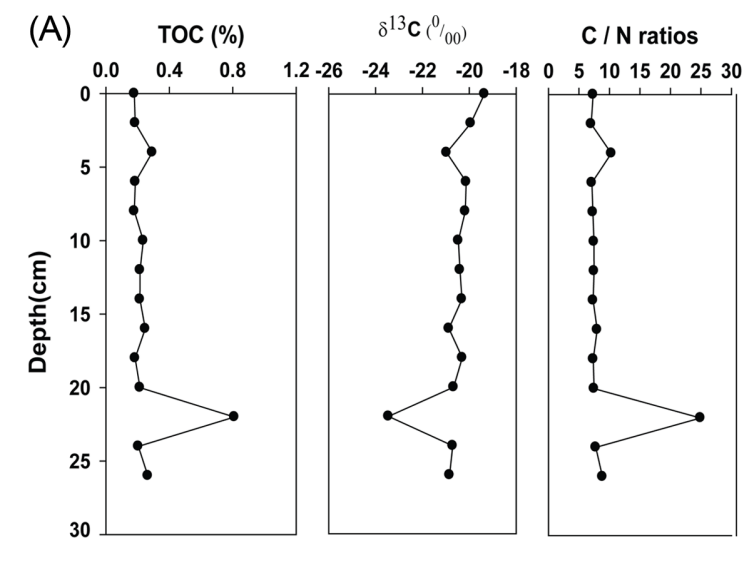

$\delta^{13} \mathbf{C}\left({ }^{0} / 00\right)$

C / $\mathrm{N}$ ratios

(B)
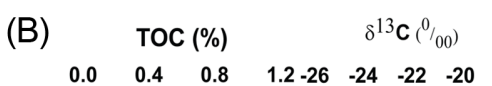

C / N ratios

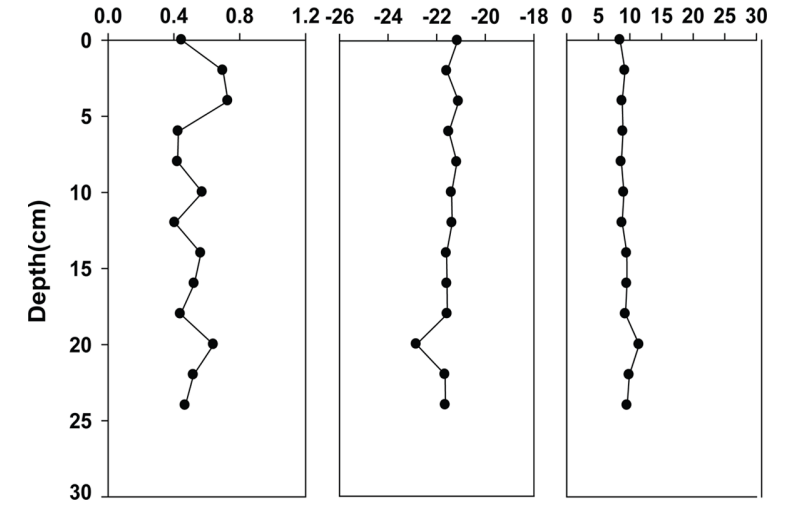

Fig. 2. Depth distributions of TOC (\%), stable carbon isotope $\left(\delta^{13} \mathrm{C}\right)$, and $\mathrm{C} / \mathrm{N}$ ratio in the sediment cores of Hwang-Do (A) and Sogeun-ri intertidal flat (B), mid-west coast of Korea

Table 1. Environmental parameters of core sediments at 2 sampling sites in February, 2013

\begin{tabular}{|c|c|c|c|c|c|c|}
\hline St. & $\begin{array}{l}\text { Core depth } \\
\text { (cm) }\end{array}$ & $\begin{array}{c}\text { Temp. } \\
\left({ }^{\circ} \mathrm{C}\right)\end{array}$ & $\begin{array}{l}\text { Density } \\
\left(\mathrm{g} / \mathrm{cm}^{3}\right)\end{array}$ & Porosity & $\begin{array}{c}\text { Mean. } \\
(\phi)\end{array}$ & $\begin{array}{l}\text { Sediment type } \\
\text { by Folk (1957) }\end{array}$ \\
\hline \multirow[t]{7}{*}{ Hwang-Do } & $0-4$ & 17.7 & 1.74 & 0.60 & 4.65 & $\mathrm{zS}^{*}$ \\
\hline & $4-8$ & 16.8 & 1.97 & 0.55 & 4.41 & $\mathrm{zS}$ \\
\hline & $8-12$ & 16.9 & 1.76 & 0.46 & 4.78 & $\mathrm{zS},(\mathrm{g}) \mathrm{sM}^{* *}$ \\
\hline & $12-16$ & 16.9 & 1.82 & 0.53 & 4.98 & $\mathrm{zS}, \mathrm{sZ} \mathrm{Z}^{* * *}$ \\
\hline & $16-20$ & 17.1 & 1.74 & 0.48 & 5.06 & $\mathrm{sZ},(\mathrm{g}) \mathrm{sM}$ \\
\hline & $20-24$ & 17.8 & 1.75 & 0.49 & 5.99 & $\mathrm{sC},(\mathrm{g}) \mathrm{sM}$ \\
\hline & $24-28$ & 19.1 & 1.84 & 0.49 & 4.42 & $\mathrm{sZ}, \mathrm{gmS}^{* * * *}$ \\
\hline \multirow[t]{8}{*}{ Sogeun-ri } & $0-4$ & 16.0 & 1.64 & 0.54 & 5.93 & (g)sM, sZ \\
\hline & $4-8$ & 15.2 & 1.90 & 0.58 & 6.07 & sZ, (g)sM \\
\hline & $8-12$ & 15.3 & 1.71 & 0.51 & 6.21 & (g)sM \\
\hline & $12-16$ & 15.1 & 1.79 & 0.48 & 6.20 & (g)sM \\
\hline & $16-20$ & 15.8 & 1.73 & 0.54 & 6.62 & (g)sM, sZ \\
\hline & $20-24$ & 16.3 & 1.76 & 0.55 & 6.77 & sZ, (g)sM \\
\hline & $24-28$ & 16.5 & 1.71 & 0.57 & 6.67 & sZ \\
\hline & $28-32$ & 17.2 & 1.73 & 0.54 & 6.67 & (g)sM \\
\hline
\end{tabular}

${ }^{*}$ silty Sand, ${ }^{* *}$ slightly gravelly sandy Mud, ${ }^{* * *}$ sandy Silt, ${ }^{* * * *}$ gravelly muddy Sand 
황도갯벌의 퇴적물 코어에서 메탄농도는 표층에서는 약 $4 \mu \mathrm{M}$ 이나 $4 \mathrm{~cm}$ 부터 $24 \mathrm{~cm}$ 깊이까지는 약 $10 \mu \mathrm{M}$ 로 일정 한 값을 보인다(Fig. $5 \mathrm{~A})$. 그러나, 소근리 갯벌에서는 $16-$

(A) Textural composition (\%) $\begin{array}{llllll}0 & 20 & 40 & 60 & 80 & 100\end{array}$

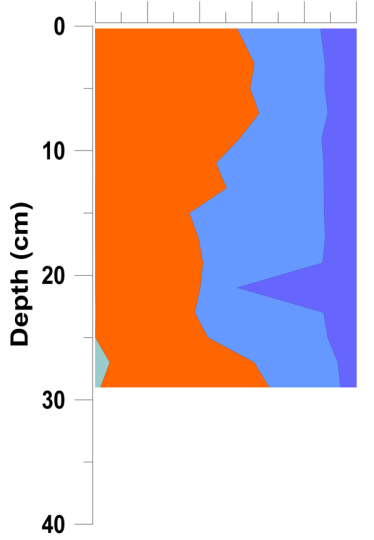

(B)

Textural composition (\%) $\begin{array}{llllll}0 & 20 & 40 & 60 & 80 & 100\end{array}$

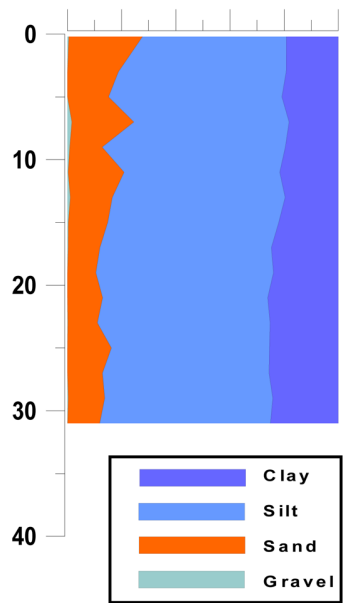

Fig. 3. Depth profiles of textural composition of core sediments of Hwang-Do (A) and Sogeun-ri intertidal flat (B), mid-west of Korea

$20 \mathrm{~cm}$ 에서 10-12 $\mu \mathrm{M}$ 로 상당히 높은 양이 측정되지만, 표 층으로 갈수록 감소하여 표층에서 약 $6 \mu \mathrm{M}$ 이 측정되었다 (Fig. 5B). 두 갯벌 지역에서 황산염의 농도는 지역별 및 퇴적 깊이에 따라 $15.38-24.72 \mathrm{mM}$ 의 범위로, 2012년 황 도 갯벌에서 측정한 농도(20.5-26.7 mM, NFRDI 2013)와 비슷하였다.

본 연구에서 분석된 n-alkane 중 탄소수 15-33까지의 농도를 Table 2에 나타내었다. 전반적으로 탄소수가 증가 할수록 지역간의 농도차이가 상대적으로 더 높게 나타남 을 확인할 수 있었다. 황도에서 $\mathrm{TOC}$ 함량이 높은 $22 \mathrm{~cm}$ 구간에서 긴 형태 사슬의 홀수 우위성 n-alkane(n-C27, n$\mathrm{C} 29, \mathrm{n}-\mathrm{C} 31)$ 의 농도가 소근리에 비해 상대적으로 더 높게 나타났다(Fig. 4). 그 중 n-alkane의 농도비((n-C27 + n$\mathrm{C} 29+\mathrm{n}-\mathrm{C} 31) /(\mathrm{n}-\mathrm{C} 15+\mathrm{n}-\mathrm{C} 17+\mathrm{n}-\mathrm{C} 19))$ 가 소근리에서 는 깊이에 따라 일정하게 분포하는 경향이 있는 반면, 황 도에서는 상대적으로 높은 농도비가 여러 퇴적 깊이에서 나타났다.

\section{퇴적환경에 따른 지질생체지표}

황도갯벌 퇴적물 코어에서 분석된 crocetane의 농도는 0.01-0.08 $\mu \mathrm{g} / \mathrm{g} \mathrm{dw}$, PMI 농도는 0.01-0.54 $\mu \mathrm{g} / \mathrm{g} \mathrm{dw}$ 이며, 메탄관련 미생물의 상대적인 분포는 메탄의 농도가 거의

Table 2. Concentration of $\mathrm{n}$-alkane (in $\mu \mathrm{g} / \mathrm{g} \mathrm{dw}$ ) in the sediment cores of Hwang-Do and Sogeun-ri intertidal flats. Cn indicates carbon number of $n$-alkane

\begin{tabular}{cccccccccccccc}
\hline Hwang-do & $\begin{array}{c}\mathbf{0 - 2} \\
\mathbf{c m}\end{array}$ & $\begin{array}{c}\mathbf{2 - 4} \\
\mathbf{c m}\end{array}$ & $\begin{array}{c}\mathbf{4 - 6} \\
\mathbf{c m}\end{array}$ & $\begin{array}{c}\mathbf{6 - 8} \\
\mathbf{c m}\end{array}$ & $\begin{array}{c}\mathbf{8 - 1 0} \\
\mathbf{c m}\end{array}$ & $\begin{array}{c}\mathbf{1 0 - 1 2} \\
\mathbf{c m}\end{array}$ & $\begin{array}{c}\mathbf{1 2 - 1 4} \\
\mathbf{c m}\end{array}$ & $\begin{array}{c}\mathbf{1 4 - 1 6} \\
\mathbf{c m}\end{array}$ & $\begin{array}{c}\mathbf{1 6 - 1 8} \\
\mathbf{c m}\end{array}$ & $\begin{array}{c}\mathbf{1 8 - 2 0} \\
\mathbf{c m}\end{array}$ & $\begin{array}{c}\mathbf{2 0 - 2 2} \\
\mathbf{c m}\end{array}$ & $\begin{array}{c}\mathbf{2 2 - 2 4} \\
\mathbf{c m}\end{array}$ \\
\hline C15 & 0.007 & 0.013 & 0.016 & 0.017 & 0.018 & 0.016 & 0.009 & 0.009 & 0.025 & 0.041 & 0.023 & 0.050 \\
C16 & 0.014 & 0.018 & 0.019 & 0.029 & 0.023 & 0.014 & 0.014 & 0.012 & 0.023 & 0.020 & 0.010 & 0.028 \\
C17 & 0.013 & 0.018 & 0.020 & 0.029 & 0.021 & 0.019 & 0.019 & 0.012 & 0.011 & 0.031 & 0.008 & 0.032 \\
C18 & 0.021 & 0.015 & 0.020 & 0.024 & 0.019 & 0.021 & 0.011 & 0.014 & 0.017 & 0.018 & 0.011 & 0.031 \\
C19 & 0.041 & 0.014 & 0.015 & 0.015 & 0.015 & 0.017 & 0.008 & 0.008 & 0.007 & 0.014 & 0.014 & 0.044 \\
C20 & 0.025 & 0.029 & 0.028 & 0.050 & 0.026 & 0.026 & 0.036 & 0.017 & 0.013 & 0.023 & 0.023 & 0.069 \\
C21 & 0.092 & 0.019 & 0.023 & 0.286 & 0.019 & 0.025 & 0.192 & 0.016 & 0.010 & 0.018 & 0.031 & 0.096 \\
C22 & 0.138 & 0.016 & 0.016 & 0.481 & 0.019 & 0.027 & 0.295 & 0.008 & 0.008 & 0.017 & 0.040 & 0.147 \\
C23 & 0.140 & 0.018 & 0.022 & 0.388 & 0.020 & 0.030 & 0.254 & 0.013 & 0.010 & 0.020 & 0.050 & 0.166 \\
C24 & 0.161 & 0.015 & 0.017 & 0.431 & 0.018 & 0.032 & 0.282 & 0.009 & 0.008 & 0.016 & 0.061 & 0.209 \\
C25 & 0.185 & 0.017 & 0.020 & 0.477 & 0.018 & 0.038 & 0.308 & 0.010 & 0.009 & 0.019 & 0.066 & 0.241 \\
C26 & 0.187 & 0.016 & 0.018 & 0.487 & 0.019 & 0.039 & 0.323 & 0.010 & 0.009 & 0.019 & 0.083 & 0.285 \\
C27 & 0.158 & 0.016 & 0.027 & 0.042 & 0.018 & 0.016 & 0.240 & 0.007 & 0.008 & 0.019 & 0.078 & 0.235 \\
C28 & 0.156 & 0.018 & 0.024 & 0.451 & 0.021 & 0.040 & 0.273 & 0.013 & 0.011 & 0.021 & 0.104 & 0.394 \\
C29 & 0.129 & 0.016 & 0.022 & 0.311 & 0.018 & 0.034 & 0.182 & 0.010 & 0.009 & 0.020 & 0.105 & 0.279 \\
C30 & 0.122 & 0.021 & 0.023 & 0.338 & 0.026 & 0.046 & 0.191 & 0.017 & 0.014 & 0.024 & 0.112 & 0.259 \\
C31 & 0.080 & 0.016 & 0.022 & 0.250 & 0.018 & 0.033 & 0.134 & 0.008 & 0.008 & 0.019 & 0.114 & 0.407 \\
C32 & 0.076 & 0.025 & 0.031 & 0.231 & 0.028 & 0.043 & 0.116 & 0.020 & 0.015 & 0.026 & 0.079 & 0.220 \\
C33 & 0.046 & 0.021 & 0.025 & 0.133 & 0.000 & 0.032 & 0.071 & 0.011 & 0.010 & 0.022 & 0.066 & 0.199 \\
\hline
\end{tabular}


Table 2. Continued

\begin{tabular}{lcccccccccccc}
\hline Sogeun-ri & $\begin{array}{c}\mathbf{0 - 2} \\
\mathbf{c m}\end{array}$ & $\begin{array}{c}\mathbf{2 - 4} \\
\mathbf{c m}\end{array}$ & $\begin{array}{c}\mathbf{4 - 6} \\
\mathbf{c m}\end{array}$ & $\begin{array}{c}\mathbf{6 - 8} \\
\mathbf{c m}\end{array}$ & $\begin{array}{c}\mathbf{8 - 1 0} \mathbf{c m} \\
\mathbf{c m}\end{array}$ & $\begin{array}{c}\mathbf{1 0 - 1 2} \\
\mathbf{c m}\end{array}$ & $\begin{array}{c}\mathbf{1 2 - 1 4} \\
\mathbf{c m}\end{array}$ & $\begin{array}{c}\mathbf{1 4 - 1 6} \\
\mathbf{c m}\end{array}$ & $\begin{array}{c}\mathbf{1 6 - 1 8} \\
\mathbf{c m}\end{array}$ & $\begin{array}{c}\mathbf{1 8 - 2 0} \\
\mathbf{c m}\end{array}$ & $\begin{array}{c}\mathbf{2 0 - 2 2} \\
\mathbf{c m}\end{array}$ & $\begin{array}{c}\mathbf{2 2 - 2 4} \\
\mathbf{c m}\end{array}$ \\
\hline C15 & 0.013 & 0.013 & 0.015 & 0.012 & 0.052 & 0.048 & 0.048 & 0.052 & 0.046 & 0.050 & 0.045 & 0.016 \\
C16 & 0.022 & 0.023 & 0.023 & 0.019 & 0.016 & 0.023 & 0.007 & 0.021 & 0.020 & 0.021 & 0.017 & 0.026 \\
C17 & 0.019 & 0.019 & 0.019 & 0.019 & 0.020 & 0.018 & 0.023 & 0.039 & 0.026 & 0.018 & 0.026 & 0.019 \\
C18 & 0.017 & 0.015 & 0.021 & 0.022 & 0.019 & 0.016 & 0.021 & 0.018 & 0.017 & 0.018 & 0.016 & 0.030 \\
C19 & 0.009 & 0.009 & 0.010 & 0.028 & 0.009 & 0.008 & 0.009 & 0.012 & 0.008 & 0.010 & 0.008 & 0.009 \\
C20 & 0.021 & 0.023 & 0.024 & 0.042 & 0.019 & 0.017 & 0.020 & 0.013 & 0.015 & 0.016 & 0.013 & 0.017 \\
C21 & 0.017 & 0.017 & 0.023 & 0.058 & 0.023 & 0.016 & 0.021 & 0.014 & 0.018 & 0.014 & 0.016 & 0.015 \\
C22 & 0.008 & 0.008 & 0.009 & 0.071 & 0.015 & 0.008 & 0.007 & 0.007 & 0.011 & 0.011 & 0.010 & 0.011 \\
C23 & 0.016 & 0.017 & 0.021 & 0.085 & 0.019 & 0.015 & 0.018 & 0.016 & 0.014 & 0.013 & 0.013 & 0.014 \\
C24 & 0.015 & 0.016 & 0.017 & 0.098 & 0.015 & 0.014 & 0.013 & 0.015 & 0.013 & 0.015 & 0.013 & 0.013 \\
C25 & 0.015 & 0.017 & 0.020 & 0.099 & 0.016 & 0.015 & 0.013 & 0.014 & 0.014 & 0.017 & 0.014 & 0.013 \\
C26 & 0.019 & 0.021 & 0.023 & 0.117 & 0.019 & 0.018 & 0.017 & 0.019 & 0.017 & 0.024 & 0.017 & 0.018 \\
C27 & 0.007 & 0.007 & 0.009 & 0.040 & 0.014 & 0.015 & 0.008 & 0.007 & 0.007 & 0.021 & 0.007 & 0.014 \\
C28 & 0.028 & 0.031 & 0.040 & 0.151 & 0.026 & 0.028 & 0.025 & 0.026 & 0.025 & 0.032 & 0.023 & 0.026 \\
C29 & 0.020 & 0.022 & 0.031 & 0.119 & 0.020 & 0.016 & 0.017 & 0.019 & 0.017 & 0.023 & 0.016 & 0.017 \\
C30 & 0.042 & 0.047 & 0.056 & 0.089 & 0.044 & 0.040 & 0.035 & 0.039 & 0.033 & 0.039 & 0.030 & 0.035 \\
C31 & 0.021 & 0.023 & 0.026 & 0.067 & 0.020 & 0.008 & 0.015 & 0.007 & 0.014 & 0.019 & 0.013 & 0.014 \\
C32 & 0.050 & 0.055 & 0.065 & 0.089 & 0.051 & 0.043 & 0.041 & 0.044 & 0.036 & 0.040 & 0.032 & 0.039 \\
C33 & 0.021 & 0.019 & 0.029 & 0.089 & 0.022 & 0.015 & 0.017 & 0.015 & 0.014 & 0.019 & 0.013 & 0.015 \\
\hline
\end{tabular}

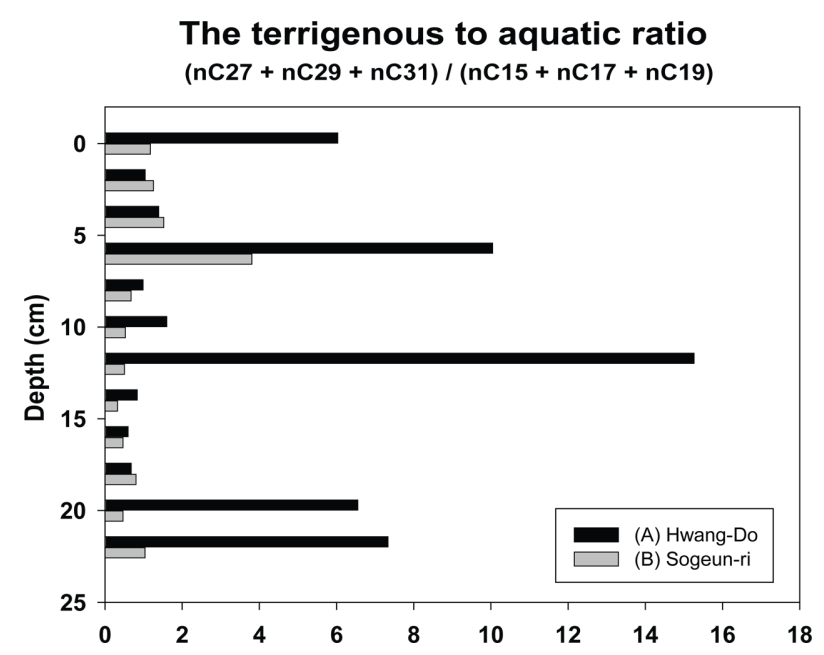

Fig. 4. Depth profile of the terrigenous to aquatic ratio $((\mathbf{n}-\mathbf{C 2 7}+\mathbf{n}-\mathbf{C 2 9}+\mathbf{n}-\mathbf{C 3 1}) /(\mathbf{n}-\mathbf{C 1 5}+\mathbf{n}-\mathbf{C 1 7}+\mathbf{n}-\mathbf{C 1 9}))$ in the sediment cores of Hwang-Do (A) and Sogeunri intertidal flat (B), mid-west of Korea

$10 \mu \mathrm{M}$ 로 일정하게 분포하고 있는 구간 $(4-12 \mathrm{~cm})$ 중에서 $6 \mathrm{~cm}$ 와 $12 \mathrm{~cm}$ 퇴적깊이에서 상대적으로 높게 분포한다 (Fig. 5A). 소근리에서는 이들의 농도가 각각 0.01-0.34 $\mu \mathrm{g} /$ $\mathrm{g} \mathrm{dw}, 0.01-0.05 \mu \mathrm{g} / \mathrm{g} \mathrm{dw}$ 의 범위를 나타냈으며, 퇴적깊이 $6 \mathrm{~cm}$ 구간에서 crocetane, PMI의 농도는 황도와 비교하여
상대적으로 매우 낮은 농도를 보였다(Fig. 5B).

황산염 환원 박테리아의 상대적인 생체량을 지시하는 $\mathrm{a}-\mathrm{C} 15: 0, \mathrm{i}-\mathrm{C} 15: 0$ 및 $\mathrm{C} 16: 1 w 5$ 의 분포는 메탄관련 미생물 의 분포 경향과는 달리 황도에서 $9.24-20.80 \mu \mathrm{g} / \mathrm{g} \mathrm{dw}$ 이며, 소근리에서 $13.12-49.99 \mu \mathrm{g} / \mathrm{g} \mathrm{dw}$ 의 범위로 지역별 뚜렷한 차이를 보였다(Fig. 5). 또한 퇴적 깊이에 따라 황도에서는 $10 \mathrm{~cm}$ 깊이에서 상대적으로 높은 값을 보이나, 소근리에 서는 표층에서 가장 높고 깊이에 따라 감소하여 $16 \mathrm{~cm}$ 깊 이에서 최소값을 나타냈다.

\section{4. 토 의}

\section{연구지역의 퇴적환경 차이}

충남 서해안에 위치하는 황도와 소근리 갯벌의 코어 퇴 적물의 입도 등의 물리적 특성과 $\mathrm{TOC}$ 와 같은 지화학적 특성들이 지역에 따라 차이가 있다(Table 1,2$)$. 일반적으 로 유기물의 함량은 퇴적물의 입도, 퇴적율, 퇴적물 내에 서의 분해작용 등과 밀접한 관계가 있으며, 소근리 코어 퇴적물에서 보듯, 세립질 입자의 경우 표면적이 조립질 입 자보다 넓어서 더 많은 양의 유기물이 흡착할 수 있다 (Lambert 1967). 모래와 실트로 구성된 황도 갯벌의 퇴적 물에 비해 세립질인 점토와 실트로 이루어진 소근리 갯벌 에서 $\mathrm{TOC}$ 가 약 2 배 정도 높게 나타났다(Figs. 2, 3). 연구 
(A)

Methane $\left(\mathrm{CH}_{4}\right)$

(uM)
Sulfate $\left(\mathrm{SO}_{4}{ }^{2-}\right)$

(mM)

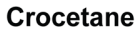

(ug/g dw)
SRB

(ug/g dw)
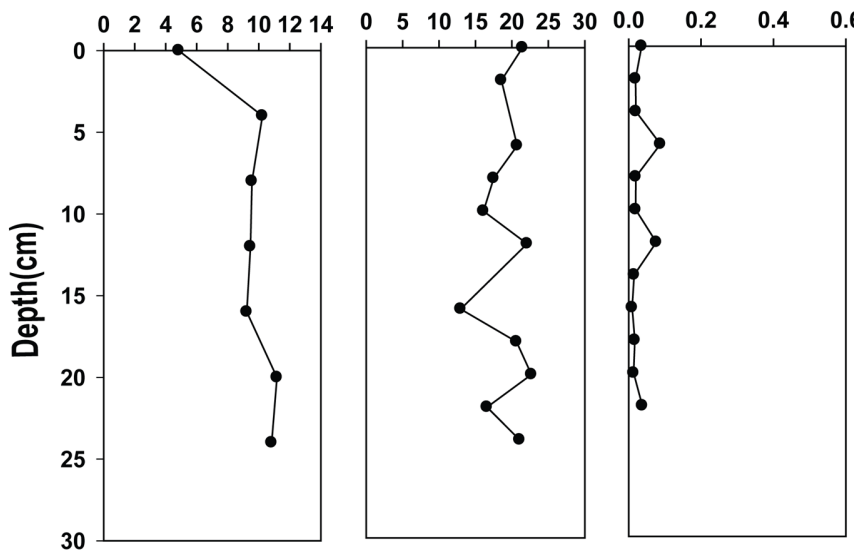

(ug $/ \mathrm{g} \mathrm{dw})$

1020304050607

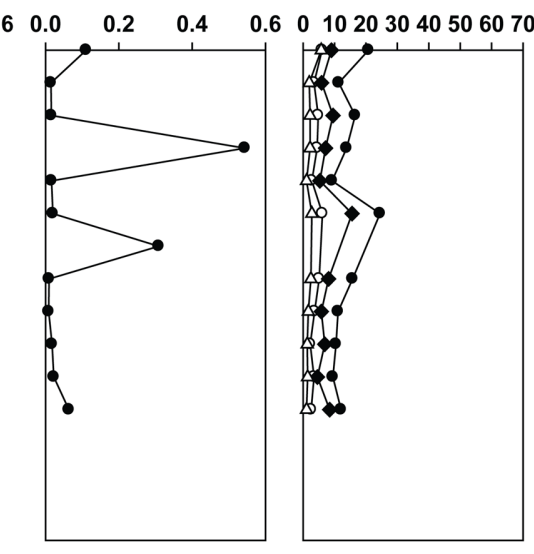

-o- i-C15:0 $\longrightarrow-\mathrm{C} 15: 0$
$-\mathrm{C} 16: 1 \mathrm{w} 5$ Sum

$(a-C 15: 0+i-C 15: 0+C 16: 1 w 5)$

(B) Methane $\left(\mathrm{CH}_{4}\right) \quad$ Sulfate $\left(\mathrm{SO}_{4}{ }^{2-}\right)$ (uM) ( $m \mathrm{M})$

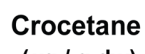
(ug/g dw)

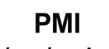

SRB (ug/g dw) (ug/g dw)

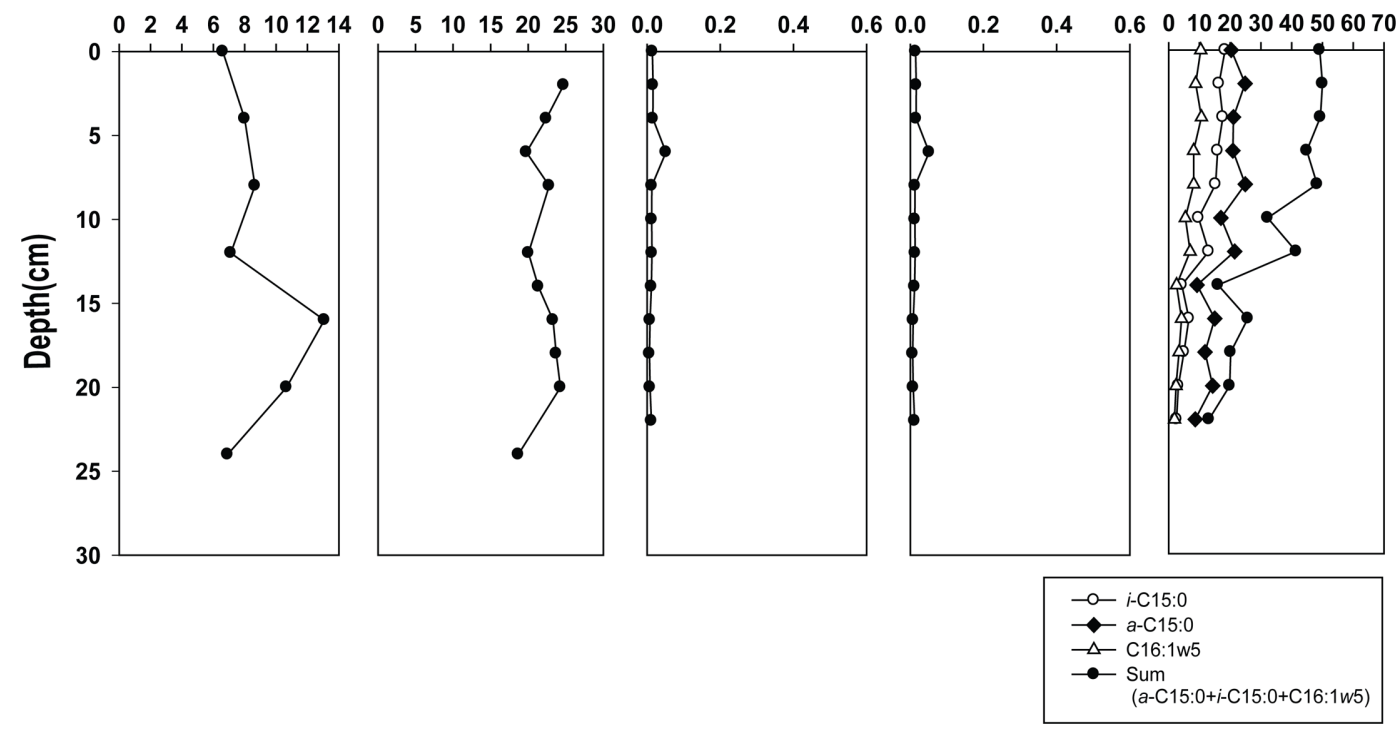

Fig. 5. Depth profile of $\mathrm{CH}_{4}$ and $\mathrm{SO}_{4}{ }^{2-}$ in pore water, and sediment lipid biomarkers (crocetane, PMI, SRB (a-C15 + $i$-C15 + C16:1w5) in the cores of Hwang-Do (A) and the Sogeun-ri intertidal flat (B), mid-west of Korea

지역에서 분석된 TOC는 0.26-0.81\%의 범위로 한강을 통 해 육지 고등식물의 리그닌 성분 또는 셀룰로오스의 유입 이 활발한 경기 강화도 갯벌(0.89-0.98\%)에 비해 상대적 으로 낮은 값을 보인다(Hyun et al. 2009). 이러한 경향은 육상기원의 유기물 유입이 $\mathrm{TOC}$ 증가에 중요한 역할을 하 고 있음을 보여주며, 연구지역 주변에 하천이나 강이 없어 서 육상으로부터 유기물의 유입이 매우 제한적으로 공급 됨을 판단할 수 있다(Woo et al. 2005; KIOST 2011). 또
한 수층의 높은 1 차 생산력으로 인해 퇴적물 내 TOC가 높은 동해 울릉분지 퇴적물에 비해(You et al. 2010), 연구 지역의 $\mathrm{TOC}$ 는 매우 낮은 범위로 나타났다. 그렇기 때문 에, 퇴적물 내 $\mathrm{TOC}$ 경향은 식물플랑크톤에 의한 1차 생 산력과 외부기원의 유기물 유입에 비례할 것이며, 퇴적물 의 입도와는 반비례할 것이라 판단된다.

$\mathrm{TOC}$ 에 영향을 미치는 유기물의 거동은 유기물 기원에 따라 크게 달라지며, 퇴적물 내 유기물의 기원을 파악하기 
위해서는 퇴적물의 $\delta^{13} \mathrm{C}, \mathrm{C} / \mathrm{N}$ 비 등이 지시자로서 자주 사 용되고 있다. 육상에서 대기 중 이산화탄소로부터 생성된 유기물의 $\delta^{13} \mathrm{C}$ 은 $-32--21 \%$ 의 범위(평균 $-27 \%$ )를 가지 며, 해양에서는 $-23--16 \%$ 의 범위(평균 $-20 \%$ )를 가진다 고 보고되고 있다(Deines 1980). 해양조류(microalgae) 기 원일 경우 $\mathrm{C} / \mathrm{N}$ 비는 5-8, 육상식물(land-plant)일 경우에 는 20 이상의 높은 값을 갖는다(Prahl et al. 1994; Silliman et al. 1996; St-Onge and Hillairemarcel 2001). 따라서 두 연구지역의 퇴적물에서 분석된 $\delta^{13} \mathrm{C}, \mathrm{C} / \mathrm{N}$ 비를 보면 해양기원의 유기물의 유입이 우세한 것으로 판단되 며, 황도의 일부 퇴적 깊이 $(22 \mathrm{~cm})$ 에서 높은 $\mathrm{TOC}$ 와 $\mathrm{C} / \mathrm{N}$ 비, 가벼운 $\delta^{13} \mathrm{C}$ 값을 보여 일시적으로 육상으로부터 다량 의 유기물이 유입된 것으로 판단된다. $\delta^{13} \mathrm{C}$ 와 $\mathrm{C} / \mathrm{N}$ 비는 퇴 적물의 속성작용 즉, 다양한 미생물의 활동에 의한 유기물 분해 및 생성 등의 정도에 따라 차이가 유발될 수 있으며 (Freudental et al. 2001; Lehmann et al. 2002), 유기물의 함량이 $0.5 \%$ 미만일 경우 질소는 대부분이 무기질소이며, 무기질소가 점토광물에 암모늄으로 결합되어 있으면 $\mathrm{C} / \mathrm{N}$ 비에 영향을 미치게 된다(Stevenson and Cheng 1972; Müller 1977). 따라서 유기물 분해에 다양한 미생물 활동 이 관계하는 퇴적환경에서는 다양한 환경으로부터 유입되 는 유기물의 기원을 파악하기 위해 탄화수소의 성분구성 이 필요하다. 육상기원의 유기물이 우세한 경우 포화지방 족 탄화수소의 긴형태 사슬 알칸 중에서도 홀수성 $\left(\mathrm{C}_{21}\right.$ $\mathrm{C}_{35}$ ) n-alkane의 존재량이 커서 Sphagnum sp. 같은 고등 식물들의 유입을 지시하는 반면, 해양 유기물이 우세한 경 우 미세조류나 박테리아 기원의 짝수성 $\left(\mathrm{C}_{15}-\mathrm{C}_{20}\right)$ n-alkane 의 존재량이 크다(Corrigan et al. 1973; Bourbonniere and Meyers 1996; Nott et al. 2000). 또한, 유기물은 퇴적물에 흡착이나 난분해성 성분의 혼합 등 퇴적물 내에서 장시간 체류하는 특징 때문에(Hyun et al. 2002), 퇴적 깊이에 따 라 총 유기물량의 변화가 뚜렷하지 않다. 반면에, n-alkane 의 상대적인 농도비 $(\mathrm{nC} 27+\mathrm{nC} 29+\mathrm{nC} 31 / \mathrm{nC} 15+\mathrm{nC} 17+$ $\mathrm{nC} 19)$ 는 황도에서 육상기원의 유기물 유입이 매우 우세하 게 나타나고 있음을 나타내는데 소근리 갯벌에는 조류에 의해 연안으로부터 유입되는 유기물(미세조류, 박테리아) 들이 우세한 반면, 황도에서는 천수만 주변의 인위적인 구 조물 건설 등의 영향으로 해수 유통이 약해짐에 따라 육 상기원의 유기물인 C3 식물(angiosperms)의 유입이 지속 되어 퇴적물 내 축적된 것으로 판단된다(Fig. 4).

\section{연구지역간의 SRB의 역할}

각 지방산 중 황산염 환원 박테리아를 지시하는 지표는 지역별 및 퇴적층의 깊이에 따라 다른 분포 양상을 나타 내고 있다(Fig. 5). 해양기원의 유기물의 유입이 우세한 소 근리 퇴적물에서는 상대적으로 조립질의 퇴적환경이며 육
상기원의 유기물 유입이 우세한 황도에 비해 표층에서 많 은 양은 황산염 환원 박테리아 지표 지방산이 검출되었 다. 이는 세립질 퇴적물의 저서환경에서는 미생물에 의한 혐기성 호흡이 우세하게 이루어지며, 높은 황산염의 농도 가 지시하는 바와 같이, 다른 유기물 분해기작(산소, 질산 염, 망간, 철의 환원)보다 황산염 환원 기작에 더 유리하게 작용할 수 있다(Jørgensen 1982; Canfiled et al. 1993). 연 구지역간 퇴적구간 별 황산염의 농도는 거의 일정하며 풍 부하게 존재하고 있음에 따라, 다른 전자수용체의 공급으 로 인한 황산염 환원 박테리아의 황산염 환원활동에 대한 제약이 발생하지 않을 것이라고 판단된다(Fig. 5). 즉, 세 립질의 퇴적환경인 소근리에서 표층에서부터 높게 나타난 황산염 환원 지표 지방산의 농도를 통해 대부분 퇴적구간 에서 황산염 환원이 우세하게 나타나고 있음을 파악할 수 있다. 그에 비해 황도에서는 조립질 퇴적환경 특성을 가짐 으로써 산소가 존재하는 표층 퇴적물에서 유기물이 대부 분 분해되어 퇴적물에 축적되는 유기물의 양이 많지 않기 때문에 전반적인 황산염 환원 박테리아의 상대적인 총 함 량이 낮지만, $10 \mathrm{~cm}$ 퇴적구간에서 황산염 환원 박테리아 는 다른 분해반응들과의 경쟁관계에서 우위에 있기 때문 에 이 구간에서 황산염 환원이 활발하게 이루어질 것으로 보인다.

한편, 다른 의견으로서 혐기성 환경의 퇴적물에서 대사 산물인 산화 제1철 이나 황화수소와 같은 환원 화합물들 이 다량으로 생성되어 미생물의 유류오염물질 분해에 전 자수용체로 이용된다는 것이다(Weiner and lovley 1998; Rooney-Varga et al. 1999; Bin et al. 2002). 소근리의 경 우 2007 년에 발생한 Hebei Spirit호의 유류유출사고로 인 해 표층 퇴적물에서 유분 및 유류오염물질(Benzene, Toluene, Ethylbenzene, Xylene, BTEX)이 확인되었으며 (KIOST 2011), 2013년 2월에도 BTEX 중 toluene 뿐만 아니라(not published), Unresolved Complex Mixture (UCM) 등이 확인되었다. $\mathrm{UCM}$ 은 전체 탄화수소 중에서 각각의 결합된 탄소와 수소가 $\mathrm{GC}-\mathrm{MS}$ 에 연결된 컬럼 (column)으로는 분리되기가 어렵기 때문에 유류로 오염된 퇴적물에서 흔히 나타난다(Rowland and Maxwell 1984; Volkman et al. 1992). 따라서, 소근리에서 높게 분석된 황 산염 환원 지표 지방산의 농도는 비교적 자연상태의 갯벌 을 유지하고 있는 황도에 비해 퇴적물 내 서식하고 있는 황산염 환원 박테리아가 상대적으로 풍부하며, 황산염 환 원 과정을 통해 toluene 및 유기오염물질을 생분해시키기 위한 것으로 보인다. 그렇기 때문에 연구지역간 황산염 환 원 박테리아에 의한 황산염 환원 차이는 유류오염물질의 존재 또한 큰 영향인자로 작용할 것으로 판단된다.

메탄관련 미생물들에 의한 메탄의 생성 및 소비와 관련 된 지질생체지표로는 crocetane과 PMI 등이 있는데(Elvert 
et al. 1999; Hinrichs et al. 1999; Pancost et al. 2001; Blumenberg et al. 2004), 두 연구지역에서 나타난 crocetane 과 $\mathrm{PMI}$ 의 농도는 황도에 비해 소근리에서 매우 낮게 나 타났다. 입도에 따른 유기물 함량 차이 및 유류오염물질의 존재로 소근리의 대부분 퇴적 구간에서 황산염 환원 박테 리아의 황산염 환원활동이 활발하게 이루어지기 때문에, crocetane과 PMI가 상대적으로 낮은 농도를 나타낸 것으 로 보인다. 메탄생성에 관련한 미생물들은 $\mathrm{CH}_{3} \mathrm{COOH}$, $\mathrm{H}_{2}, \mathrm{CO}_{2}$ 와 같은 주요한 전자공여체의 획득에 있어 황산염 환원 박테리아와 경쟁하게 되는데, 황산염 환원 박테리아 의 황산염 환원활동으로 인해 생성된 황화수소의 강한 독 성으로 인해 그 활성이 제어될 수 있다(Hargrave et al. 1993; Holmer et al. 2005). 따라서, 소근리에서 활발한 황 산염 환원과정은 메탄관련 미생물의 메탄생성 과정에 직 접적으로 영향을 미쳐 상대적인 생체량 뿐 만 아니라 이 들에 의한 메탄생성 활동은 황도에 비해 상대적으로 미비 할 것으로 판단된다. 황도의 $10 \mathrm{~cm}$ 퇴적층에서 황산염 환 원 박테리아의 황산염 환원 과정이 상대적으로 활발하게 일어나고 하층으로 갈수록 황산염 환원 지표 지방산의 농 도가 점차 감소하는 경향이 나타남에 따라, 황산염 환원 박테리아의 기질간 경쟁이 약해져 $\mathrm{H}_{2}, \mathrm{CO}_{2}, \mathrm{CH}_{3} \mathrm{COOH}$ 등을 메탄관련 미생물들이 활발히 이용하여 메탄의 생성 이 이루어질 것이라 판단된다. 반면, $6 \mathrm{~cm}$ 구간에서 crocetane과 $\mathrm{PMI}$ 의 농도가 상대적으로 높게 나타났고 황 산염 환원 지표 지방산의 농도 또한 지속적으로 높게 유지 되고 있기 때문에, 기질경쟁으로 인한 전자공여체의 획득 과정 보다는 직접적인 경쟁을 피해 단독적으로 수행될 수 있는 메탄생성 과정에 대한 가능성을 고려해 볼 수 있을 것 이다. 특히, 메틸화된 기질(methylamines, dimethylsulfide) 은 메탄관련 미생물들이 황산염 환원 박테리아와 직접적 인 경쟁을 피해 단독적으로 메탄생성을 수행할 수 있다고 알려져 있기 때문이다(Madigan et al. 2003).

앞서 언급한 바와 같이, 연구지역간 메탄관련 미생물의 지질생체지표 농도는 뚜렷한 차이를 보이고 있는데 유기 물의 함량과 메탄관련 미생물간의 높은 상관성이 있음에 도 불구하고(Kaneko et al. 2013), 상대적으로 유기물 함 량이 낮은 황도에서 crocetane과 PMI의 농도가 높게 나타 났다. 이는 황도의 일부 퇴적구간에서 서식하고 있는 미생 물에 의한 현재의 메탄생성 활동(methanogesis)과 퇴적물 내 과거 메탄생성의 흔적(fossil)들이 혼합되어 있음에 따 라(Kaneko et al. 2010), crocetane과 PMI의 농도가 높게 나타남에도 불구하고 퇴적물 내 메탄의 농도가 일정한 경 향이 나타나 현재의 생물발효기원의 메탄생성 과정은 잠 재적으로 낮아질 것이라 판단된다. 한편, 소근리에서 메탄 의 농도와 지질생체지표간에 뚜렷한 경향이 나타나지 않
는 것은 서로 다른 퇴적물 특성에 의한 영향으로서 조립 질에 비해 세립질 퇴적층에서는 공극률이 높아 수리전도 도(hydraulic conductivity)가 낮고 메탄과 같은 기질들의 플럭스(flux)가 감소되기 때문에, 퇴적층 내 지화학 특성 과 메탄관련 미생물간의 상관성이 낮게 나타날 수 있다 (Wilms et al. 2007). 따라서 소근리의 퇴적구간 $(16 \mathrm{~cm})$ 에 서 메탄과 crocetane, $\mathrm{PMI}$ 의 농도 간의 뚜렷하지 않는 차 이는 세립질 퇴적특성 때문이며, 실질적인 메탄의 농도는 낮게 분포될 것이라 판단된다.

\section{5. 결 론}

본 연구는 지화학 성분 및 지질생체지표 분석을 통하여 비교적 자연상태를 유지하고 있는 갯벌(황도)과 유류오염 을 경험한 갯벌(소근리)에서 유기물의 기원을 파악하고 서 로 다른 퇴적환경에서 미생물들에 의한 혐기성 유기물 분 해 과정의 이해뿐 만 아니라 퇴적 깊이에 따른 분포 경향 및 상대적인 중요성을 살펴보고자 하였다.

입도분석 결과 연구지역에서 서로 다른 퇴적상을 나타 내고 있으며 이에 따라 퇴적물 내 TOC 차이를 보였다. 탄 화수소 구성을 통한 유기물의 기원 분석 결과, 황도와 소 근리에서 퇴적 깊이에 따라 퇴적물에 유입된 기원 차이를 확인할 수 있었으며, 이에 따라 두 지역에서 유기물의 분 포 차이는 외부기원의 유기물 유입에 비례하는 경향을 보 이며 퇴적물의 입도와는 반비례하는 경향을 보였다.

연구지역 간의 퇴적환경 및 유기물의 양과 질에 따라 혐기성 환경에서 황산염 환원 박테리아의 황산염 환원활 동에 차이가 나타나고 있음을 확인할 수 있었으며, 특히 소근리에서 존재하는 유류오염물질을 분해시키기 위해 황산염 환원 박테리아의 황산염 환원 활동이 두드러지게 나타나고 있음을 확인할 수 있었다. 이러한 황산염 환원 박테리아의 황산염 환원 반응으로 생성되는 부산물인 황 화수소들이 최종 유기물 분해작용인 메탄생성과정에도 영향을 미칠 수 있기 때문에 이들에 의한 황산염 환원 활 동은 혐기성 유기물 분해 과정에 큰 영향 인자로 나타났 다. 그렇기 때문에 지화학 및 지질생체지표 분석을 통해 퇴적물 내의 생지화학적인 물질순환에 중요한 기능을 담 당하고 있는 황산염 환원 박테리아의 황산염 환원과 메탄 관련 미생물들에 의한 메탄생성 과정은 서로 다른 퇴적환 경 및 혐기성 유기물 분해차이를 파악하는 유용한 지표로 서 사용될 수 있음을 확인하였다. 추후, 다양한 환경변화 에 따른 갯벌 내 유기물의 생지화학적인 거동을 이해하기 위해서는 지속적인 환경 모니터링이 필요하며, 이를 통해 연안환경에서 유기물 거동에 관하여 필수적인 정보를 제 공할 것이라 여겨진다. 


\section{사 사}

“이 논문은 2013년 해양수산부 재원으로 한국해양과학 기술진흥원의 지원을 받아 수행된 연구(관할해역 해양지 질 및 지구조 연구)" 및 한국해양과학기술원 “위성기반 연 근해 해양환경분석기술 개발(SATCOM) (PE98927)" 사업 의 지원을 받아 수행된 연구입니다. 본 연구에 있어 많은 도움을 주신 한양대학교 김성한님과 유정식님께 감사의 말씀 드립니다.

또한 논문 심사를 맡아주신 익명의 심사위원님께 감사 드립니다.

\section{참고문헌}

Alongi DM (1995) Decomposition and recycling of organic matter in muds of the Gulf of Papua, northern Coral Sea. Cont Shelf Rea 15:1319-1337

Bin L, Van Verseveld HW, Roling WFM (2002) Microbial aspect of anaerobic BTEX degradation. Biomed Environ Sci 15:130-144

Beller HR, Grbic-Gaic D, Reinhard M (1992) Microbial degradation of toluene under sulfate-reducing conditions and the influence on iron on the process. Appl Environ Microbiol 50:786-793

Blumenberg M, Seifert R, Reitner J, Pape T, Michaelis W (2004) Membrane lipid patterns typify distinct anaerobic methanotrophic consortia. P Natl Acad Sci Usa 101: 11111-11116

Bourbonniere RA, Meyers PA (1996) Sedimentary geolipid records of historical changes in the watersheds and productivities of Lakes Ontario and Erie. Limnol Oceanogr 41:352-359

Canfield DE, Thamdrup B, Hansen JW (1993) The anaerobic degradation of organic matter in Danish coastal sediment: Iron reduction, manganese reduction and sulfate reuction. Geochim Cosmochim Ac 57:3869-3883

Capone DG, Keiene R (1988) Comparison of microbial dynamics in marine and freshwater sediments: Contrasts in anaerobic carbon catabolism. Limnol Oceanogr 33:725749

Cho HY, Lee JH, Hyun JH (2004) Bacterial community structure and diversity using $16 \mathrm{~S}$ rDNA anlaysis in the intertidal sediment of gwanghwa Island. Korean J Microbiol 40(3):189-198 (in Korean)

Choi JK, Ryu JH (2011) A study on the sedimentary facies change in the tidal flat using high spatial resolution remotely sensed data. Econ Eviron Geol 44(1):59-70 (in Korean)
Corrigan D, Kloos C, O’Connor CS, Timoney RF (1973) Alkanes from four types of Sphagnum moss. Phytochem 12:213-214

Dzierzewicz Z, Cwalina B, Kurkiewicz S, Chodurek E, Wilczok T (1996) Intra-species variability of cellular fatty acids among soil and intestinal strains of Desulfovibrio desulfuricans. Appl Environ Microbiol 62:3360-3365

Elvert M, Suess E, Whiticar MJ (1999) Anaerobic methane oxidation associated with marine gas hydrates: superlight C-isotopes from saturated and unsaturated C20 and C25 irregular isoprenoids. Naturwissenschaften 86:295-300

Elvert M, Boetius A, Knittel K, Jørgensen BB (2003) Characterization of specific membrane fatty acids as chemotaxonomic markers for sulfate-reducing bacteria involved in anaerobic oxidation of methane. Geomicrobiol $\mathrm{J}$ 20:403-419

Ensely BD, Suflita JM (1995) Metabolism of environmental contaminations by mixed and pure cultures of sulfatereducing bacteria. In: Barton LL (ed) Sulfate-Reducing. Plenum Press, New York, pp 293-332

Feio MJ, Beech IB, Carepo M, Lopes JM, Cheung CWS, Franco R, Guezennec J, Smith JR, Mitchell JI, Moura JJG, Lino AR (1998) Isolation and characterisation of a novel sulphate-reducing bacterium of the Desulfovibrio Genus. Anaerobe 4:117-130

Folk RL, Ward WC (1957) Brazos river bar: A study in the significance of grain size parameters. J Sediment Petrol 27:3-26

Freudenthal T, Wagner T, Wenzhöfer F, Zabel M, Wefer G (2001) Early diagenesis of organic matter from sediments of the eastern subtropical Atlantic: evidence from stable nitrogen and carbon isotopes. Geochim Cosmochim Ac 65:1795-1808

Giblin AE, Hopkinson CS, Tucker J (1997) Benthic metabolism and nutrient cycling in Boston Harbor, Massachusetts. Estuaries 20:346-364

Greenwood PF, Summons RE (2003) GC-MS detection and significance of crocetane and pentamethylicosane in sediments and crude oils. Org Geochem 34:1211-1222

Hargrave BT, Duplisea DE, Pfeiffer E, Wildish DJ (1993) Seasonal changes in benthic fluxes of dissolved oxygen and ammonium associated with marine cultured Atlantic salmon. Mar Ecol Prog Ser 96:249-257

Hansen TA (1993) Carbon metabolism of sulfate-reducing bacteria. In: Odom JM, Singleton R (eds) the sulfatereducing bacteria: contemporary perspectives. SpringerVerlag, New York, pp 21-40

Hinrichs KU, Hayes JM, Sylva SP, Brewer PG, DeLong EF (1999) Methane consuming archaea and bacteria in 
marine sediments. Nature 398:802-805

Holmer M (1996) Composition and fate of dissolved organic carbon derieved from phytoplankton detritus in coastal marine sediments. Mar Eco Prog Ser 141:217-228

Holmer M, Wildish D, Hargrave B (2005) Organic enrichment from marine finfish aquaculture and effects on sediment biogeochemical processes. In: Barceló, Damià, Kostianoy, Andrey G (eds) The Handbook of Environmental Chemistry, Vol. 5. Springer, New York, pp 181-206

Hyun JH, Kim KH, Kwon KK, Lee JH, Lee HK, Kim SJ, Kim KH (2002) Total microbial biomass measured by ATP in three marine sedimentary environments. Korean J Microbiol 38:119-126 (in Korean)

Hyun JH, Mok JS, Cho HY, Cho BC, Choi JK (2004) Anaerobic mineralization of organic matter and sulfate reduction in summer at Ganghwa intertidal flat, Korea. J Korean Wet Soc 6:132 (in Korean)

Hyun JH, Mok JS, Cho HY, Kim SH, Lee KS, Kostka, JE (2009) Rapid organic matter mineralization coupled to iron cycling in intertidal mud flats of the Han River estuary, Yellow Sea. Biogeochem 92:231-245

Jahnke C (1995) Quantifying the role of heterotrophic bacteria in the carbon cycle: A need for respiration rate measurements. Limnol Oceanogr 40:436-441

Jhonston R (1970) The decomposition of crude oil residence in sand columns. J Mar Biol Ass UK 50:925-937

Jørgensen BB (1982) Mineralization of organic matter in the sea bed-the role of sulphate reduction. Nature 96:643645

Kaneko M, Shingai H, Pohlman JW, Naraoka H (2010) Chemical and isotopic signature of bulk organic matter and hydrocarbon biomarkers within mid-slope accretionary sediments of the northern Cascadia margin gas hydrate system. Mar Geol 275:166-177

Kaneko M, Naraoka H, Takano Y, Ohkouchi N (2013) Distribution and isotopic signatures of archaeal lipid biomarkers associated with gas hydrate occurrences on the northern CascadiaMargin. Chem Geol 343:76-84

Kim YS (1989) The sedimentology of Holocene intertidal deposits in Cheonsu Bay, west coast of Korea. Jour. Korean Earth Science Society 10(1):134-151 (in Korean)

KIOST (2011) Environmental assessment of oil spill and environmental restoration research. Korea Institute of Ocean Science \& Technology, 37 p (in Korean)

Koster IW, Rinezema A, de Vegt AL, Lettinga G (1986) Sulfide inhibition of methanogenic activity of granular sludge at various pH-levels. Wat Res 20:1561-1567

Lambert SM (1967) Functional relationship between sorption in siol and chemical structure. J Agric Food Chem. 15:
$572-576$

Lee DH, Kim JH, Bahk JJ, Cho HY, Hyun JH, Shin KH (2013) Geochemical signature related to lipid biomarkers of ANMEs in gas hydrate-bearing sediments in the Ulleung Basin, East Sea (Korea). Mar Petrol Geol 47:125-135

Lehmann MF, Bernasconi SM, Barbieri A, McKenzie JA (2002) Preservation of organic matter and alteration of its carbon and nitrogen isotope composition during simulated and in situ early sedimentary diagenesis. Geochim Cosmochim Ac 66:3573-3584

Madigan MT, Martinko JM, Parker J (2003) Brock Biology of Microorganisms, 10th edn. Pearson Education Inc., Upper Saddle River, NJ, $1152 \mathrm{p}$

Martens CS, Berner RA (1974) Methane production in the interstitial waters of sulfate depleted marine sediments. Science 185:1167-1169

Maslen E, Grice K, Gale JD, Hallmann C, Horsfield B (2009) Crocetane: A potential marker of photic zone euxinia in thermally mature sediments and crude oils of Devonian age. Org Geochem 40:1-11

Minami K, Tanimoto Y, Tasaki M, Ogawa S, Okamura K (1988) Influence of sulfate on methane fermentation in a defined medium. Wat Sci Tech 20:1561-1567

MOF (2005) Tidal Ecosystems, Research and Study on the Sustainable Use Methods (Inventory of Tidal Flats in Korea). Ministry of Oceans and Fisheries, Se-Jong (in Korean)

Mok JS, Cho HY, Hyun JH (2005) Rates of anaerobic carbon mineralization and sulfate reduction in association with bioturbation in the intertidal mudflat of Gwanghwa, Korea. J Korean Soc Oceanogr 10(1):38-46 (in Korean)

Müller PJ (1977) C/N ratios in Pacific deep-sea sediments: effect of inorganic ammonium and organic nitrogen compounds sorbed by clays. Geochim Cosmochim Ac 41: $765-776$

NFRDI (2013) The fifth report of environmental assessment of Fishery survey. National Fisheries Research \& Development Institute, Busan, 127 p (in Korean)

Nott CJ, Xie SC, Avsejs LA, Maddy D, Chambers FM, Evershed RP (2000) n-Alkane distributions in ombrotrophic mires as indicators of vegetation change related to climatic variation. Org Geochem 31:231-235

Oremland RS, Polcin S (1982) Methanogenesis and sulphate reduction: competitive and non-competitive substrates in estuarine sediments. Appl Environ Microbiol 44:12701276

Pancost RD, Hopmans EC, Sinninghe Damsté JS (2001) The MEDINAUT Ship board Scientific Party. Archaeal lipids in Mediterranean cold seeps: molecular proxies for 
anaerobic methane oxidation. Geochim Cosmochim Ac 65:1611-1627

Prahl FG, Ertel JR, Goni MA, Sparrow MA, Eversmeyer, B (1994) Terrestrial organic carbon contributions to sediments on the Washington margin. Geochim Cosmochim Ac 58:3035-3048

Rooney-Varga JN, Anderson RT, Fraga JL, Ringelberg D, Lovley DR (1999) Microbial communities associated with anaerobic benzene degradation in a petroleum-contaminated aquifer. Appl Environ Microbial 65:3056-3063

Rowland SJ, Maxwell JR (1984) Reworked triterpenoid and steroid hydrocarbons in a recent sediment. Geochim Cosmochim Ac 48:617-624

Samiullah Y (1985) Biological Effects of Marine Oil Pollution. Oil Petrochem Pollut 2:235-264

Silliman JE, Meyers PA, Bourbonniere RA (1996) Record of postglacial organic matter deliverly and burial in sediments of Lake Ontario. Org Geochem 24:443-472

St-Onge G, Hillaire-Marcel C (2001) Isotopic constraints of sedimentary inputs and organic carbon burial rates in the Saguenay Fjord, Quebec. Mar Geol 176:1-22

Stevenson FJ, Cheng CN (1972) Organic geochemistry of the Argentine Basin sediments; Carbon-nitrogen relationships and quaternary correlations. Geochim Cosmochim Ac 36:653-671

Thamdrup B, Canfield DE (1996) Pathways of carbon oxidation in continental margin sediments off central Chile. Limnol Oceanogr 41(8): 1629-1650

Thamdrup B (2000) Bacterial manganese and iron reduction in aquatic sediments. Adv Microbial Ecology 16:41-84

Thiel V, Peckmann J, Seifert R, Wehrung P, Reitner J, Michaelis W (1999) Highly isotopically depleted isoprenoids: molecular markers for ancient methane venting. Geochim Cosmochim Ac 63:3959-3966

Volkman JK, Holdsworth DG, Neill GP, Bavor Jr HJ (1992) Identification of natural, anthropogenic and petroleum hydrocarbons in aquatic sediments. Sci Total Environ 112:203-219

Yang JY, Chung KH, Jin YK, Shin KH (2011) Characterizing lipid biomarkers in methanotrophic communities of gas hydrate-bearing sediments in the Sea of Okhotsk. Mar Pet Geol 28:1884-1898

You OR, Mok JS, Kim SH, Choi DL, Hyun JH (2010) Comparison of sulfate reduction rates associated with geochemical characteristics at the continental slope and basin sediments in the Ulleung Basin, East Sea. Ocean and Polar Res 32(3):299-307 (in Korean)

Weiner JM, Lovley DR (1998) Anaerobic benzene degradation in petroleum-contaminated aquifer sediments after inoculation with a benzene-oxidizing enrichment. Appl Environ Microbiol 64:775-778

Wilms R, Sass H, Kolpke B, Cyponka H, Engelen B (2007) Methane and sulfate procleswithin the subsurface of a tidal flat are reflected by the distribution of sulfatereducing bacteria and methanogenic archaea. FEMS Microbiol Ecol 59:611-621

Woo HJ, Choi JU, Ryu JH, Choi SH, Kim SR (2005) Sedimentary environments in the hwangdo tidal flat Cheonsu bay. J Korean Wet Soc 7(2):53-67 (in Korean)

Received Dec. 27, 2013

Revised Feb. 3, 2014

Accepted Mar. 9, 2014 